\title{
CIRCULAR BUSINESS MODELS IN TEXTILES AND APPAREL SECTOR IN SLOVAKIA
}

\author{
Daňo, F., Drábik, P., Hanuláková, E.
}

Ferdinand Daňo / University of Economics Bratislava, Faculty of Commerce, Department of Marketing, Dolnozemská cesta 1, 85235 Bratislava, Slovak Republic, Email: ferdinand.dano@euba.sk.

Peter Drábik / University of Economics Bratislava, Faculty of Commerce, Department of Marketing, Dolnozemská cesta 1, 85235 Bratislava, Slovak Republic, Email: peter.drabik@euba.sk.

Eva Hanuláková / University of Economics Bratislava, Faculty of Commerce, Department of Marketing, Dolnozemská cesta 1, 85235 Bratislava, Slovak Republic, Email: eva.hanulakova@euba.sk.

\begin{abstract}
The circular economy is characterized as regenerative economy that aims to preserve the greatest value of products and materials. Currently, the transition to the circular economy is not only a necessity, but it gradually becomes a social and economic paradigm. The implementation of the circular economy gradually changes and will change the nature and intensity of every sector regardless of its reproductive cycle. For producers, particularly in the rapidly growing sectors, the development of innovative business models will be essential to comply with the principles of the circular economy. The fastest growing sector includes the textiles and clothing industry. The implementation of innovative business models in the field of textile and clothing industry is thus a challenge that the sector is facing. Slovakia as EU member state is facing the same challenge. Bodies operating in the textile and clothing industries must be gradually prepared for changes that brings the legislation and get ready for the trends that determine the changes mentioned. The article presents the results of research that shows the potential of the Slovak textile and clothing producers, coupled with the transition to the aforementioned new economic model, with a focus on implementing new circular business models into their activities, benefits and disadvantages of this procedure and the limits of implementation new business models into the activities of entities operating in the textile clothing industry in Slovakia.

Implications for Central European audience: This paper aims to contribute to the development of a topical and beneficial subject-matter related to transition from a linear to a circular economy in Central Europe. This entails knowledge on the imminent obligations of producers in one of the fastest growing sectors of Central European economies, i.e. in the textile and clothing industry. Such knowledge enriches the existing business models with a new business paradigm. In theoretical terms, this knowledge creates a platform for further scientific research potential and economic, business, and management education at universities. In practical terms, this knowledge represents a proactive approach of producers to the creation and implementation of innovative business models.
\end{abstract}

Keywords: circular economy; circular business model; textiles and apparel sector JEL Classification: L26, Q56 


\section{Introduction}

The concept of circular economy is a new way of finding relationships between sectors, customers and natural resources. It represents the economic system in which the products are carried out in closed circles or cycles. The circular economy is characterized as regenerative economy that aims to preserve the greatest value of products and materials. The result of this process should be to create a closed system that will enable long time span, reuse, renovation, re-manufacturing and recycling of products and materials. This is the system model, which has alpha and omega of resource efficiency and its maximum use beyond the traditional supply chain.

The notion of circular economy first emerged in 1990 (Pearce \& Turner, 1990). However, the first research focused on closed systems was published already in 1966 (Boudling, 1966). The article highlights open and closed systems, with a particular emphasis on the interaction between environment and economy. From this point of view, economic success should not be measured by the performance of industrial production, but the nature, scale, quality and complexity of the natural and human resources available. Boudling was one of the first economists who presented the paradigm of the circular economy as a long-term economic system that follows growth, sustainability and zero waste.

The involvement of the private sector highlighting business opportunities in industrial production have been emphasized since 1981 (Stahel \& Reday-Mulvey, 1981). The main objective was to support the economy, based on a system of product loops, consisting of reuse, repair and recycling.

In the coming decades, the idea of extending the product lifecycle to minimize material and energy flows about the environmental protection and to promote the transition to a sustainable society has continued, taking into account the natural resources (Stahel, 1982). It further improved the model of the circular economy based on the precautionary approach by introducing the concept of "pre-cycling", which covers all activities carried out in the early stages of the product lifecycle, in order to prevent the creation of waste (O'Rorke, 1988). In essence, this means introducing resource consumption management instead of concentrating on waste management.

Andersen has designed a simplified model of the circular economy; in which natural resources transform production processes into products intended for consumption, thus creating benefits and wealth. The extraction of raw materials, production and consumption produce waste, which could return to the production as an input through recycling (Andersen, 2006).

From the 90 s of the last century, research of products and services are beginning to focus on the economic prosperity associated with resource sustainability management. The Increased orientation of services, instead of products is intended to lead to simpler design of systems with minimal environmental impacts while maintaining economic prosperity (Tukker \& Tischner, 2006). Gradually, the shift from the production to the sales concept, to services rather than goods, has been emphasized. In this model of transition to a serviceoriented economy, the circular economy is considered a key concept that highlights major changes in current business models (Stahel, 2010). 
Currently, the transition to the circular economy is not only a necessity, but it gradually becomes a social and economic paradigm. It forms part of the political agenda on the macro level; it gets to the centre of attention on the micro-level and is the subject of several research projects. Research is mainly focused on waste, resource use and environmental impact, but with a minimal focus on economic and business perspectives. That kind of research, without pointing to economic and business benefits, could limit the transition of businesses to the circular economy because of the lack of awareness and motivation. The research and related processes of the successful transition of businesses to the circular economy should focus on (1) waste as a factor of pollution and/or environmental protection and as an input material forming part of a (new) product, (2) regenerative use of natural resources, (3) economic benefits for business operators and last but not least to (4) customers as key holders of these changes at all stages of their consumer behaviour and decision-making. These four perspectives ensure the simultaneous alignment of environmental protection requirements concerning the limitation of resources, business interests, needs and customer preferences.

The implementation of the circular economy gradually changes and will change the nature and intensity of every sector regardless of its reproductive cycle. This will require a review of the partnerships and the setting up new cooperation models, the integration of activities currently considered as a secondary business (repairs, re-grazing, etc.), reverse supply chains, value creation for the customer, and modification of the enterprise value chain in order to create a sustainable and/or circular business model. In the framework of sustainable business models, descriptive research is already being carried out (Bocken, Short, Rana, \& Evans, 2014). Research is devoted, among other things, to the integration of the circulation of business models, product design, and supply chain and product lifecycle management, thus supporting the concept of reassessment of the traditional concept towards the design of several concepts of the product lifecycle.

The aim of our article is to highlight the potential of Slovak companies (producers) operating in the textiles and clothing industry and their current and potential readiness for a transition to new circular business models. For producers, particularly in the rapidly growing sectors, the development of innovative business models will be essential to comply with the principles of the circular economy. The textile and clothing industry is one of the fastestgrowing industries and is considered the second most polluting industry. World production of fibre has been growing steadily in recent decades, and a significant increase is expected in the near future. The largest part of the fibre is heading to the clothing industry, whose main outputs are garments and household textiles, the durability of which is constantly decreasing. At the same time, the complexity of their material composition is increasing. For this reason, the issue of proper handling textiles after their lifetime (Piribauer \& Bartl, 2019) is becoming increasingly important.

\section{Literature review}

\subsection{Circular business models}

The transition to the circular economy concerns business operators, regardless of their size and country of origin. One way to help these, especially smaller business operators with the transition to the new economic model are to systematize knowledge of the substance of circular models and tools for their implementation into practice. 
The literature presents several sophisticated and validated circular business models, their design and tools for their formation (Osterwalder \& Pigneur, 2010; Wirtz, 2011). However, their universal use is limited and does not meet the current requirements for their implementation in the business activity (van Renswoude, ten Wolde, Joustra, 2015).

The basic principles and elements of circular business models can be inferred from the main principles of the circular economy. In the literature, such elements are defined differently, for example: the concept of ReSOLVE (regenerate, share, optimize, create, virtualize, exchange), ways of forming circular value (van Renswoude et al., 2015), normative requirements for business models (Boons \& Lüdeke-Freund, 2010) and integration areas (Laubscher \& Marinelli, 2014).

The literature presents several approaches to the typology of circular business models. The following classification criteria tend to be used to indicate:

- Resource creation value (Lacy, Rosenberg, Drewell, \& Rutqvist, 2013; van Renswoude et al., 2015)

- Values in service and product systems (Tukkler \& Tischner, 2006; De Jong, Engelaer, \& Mendoza, 2015; Planing, 2015).

- Design strategies for extending the life of the product (Bakker, Wang, Huisman, \& den Hollander, 2014).

- The cycle of product/component/material in material loops (Planing, 2015).

- $\quad$ Mixed criteria (Lüdeke-Freund, 2010).

Individual approaches often overlap, and distinctive criteria are unclear. These discrepancies should be removed or eliminate conceptual access to the development of circular business models. Stubbs and Cocklin have developed the concept of a circular business model, which consists of two types of attributes - structural and cultural. Each type has its economic, environmental, social and holistic characteristics (Stubbs \& Cocklin, 2008). Another conceptual approach is the process model of changing the business model to the circular model through interactions between individuals and groups inside and outside the enterprise (Roome \& Louche, 2015).

Literature also lists the tools for the formation and implementation of circular business models. It is worth mentioning the model by Joustra, de Jong \& Engelaer, which was developed to support small and medium-sized enterprises in the event of a transition to the circular economy (Joustra, de Jong \& Engelaer, 2013). It is a five-phase model that includes information on the circular economy and on the readiness of the company, partners and all stakeholders in the supply chain to move from linear to a circular economy. Subsequently, the opportunities that could bring products into the circular business model are identified; the services that could be provided by the enterprise together with the procedure for creating this model are identifiable so that it is implemented in practice. In the last step, it is determined whether there is a value that customers expect and for which they will be willing to pay.

Renswoude et al. developed a methodology to improve the transition of businesses from the linear economy into a more circular form of business (van Renswoude et al., 2015). Osterwalder and Pigneur (2010) have proposed five phases of designing business models process that include mobilization, understanding, design, implementation and management. 
The literature also outlines factors related to the introduction of circular business models into practice. These relate mostly to general factors as conditions to be met to ensure the profitability of closed circles (De Winter, 2014; Planing, 2015), human resources (Joustra et al., 2013; Lacy et al., 2014; Scott, 2015), political system and legislation (Ellen MacArthur Foundation, 2015; Scott, 2015), IT and data management (Parlikad, McFarlane, Fleisch, \& Gross, 2015; Scott, 2015).

Procedures of their evaluation are also subject of reflection on circular business models and their introduction into business activities. Laubscher and Marinelli indicate the measurement of ecological footprint and its reduction, direct financial value through the recovery of materials and assets and its growth through new business models (Laubscher \& Marinelli, 2014).

The CANVAS model is generally considered the most comprehensive circular business model, developed by Osterwalder and Pigneur (Osterwalder \& Pigneur, 2010). It is also considered as a starting point for the creation of other circulating business models since each business model is, to some extent, linear and circular at the same time. It should be noted, however, that this model supports the process of designing the circular business model, but does not indicate how the principles of the circular economy or the business activities in which the principles of the circular economy are implemented relate to elements of a particular business model.

\subsection{Circular business models in the textile and clothing industry}

The textiles research, technology and industry experts from across Europe named three powerful innovation trends that will affect the industry in the coming years, all of which are very closely related to the new circular economic model (Koszewska, 2018). These are (Walter, 2016):

- Digitization of products, their design, manufacturing, distribution and retail processes, consumer/end-user interaction, factories, workplaces and supply chains.

- Sustainability, circularity and resource efficiency of materials, processes and overall business operations; this trend requires transparent supply chains meeting the environmental, health and social standards.

- New business and consumption models based on the sharing of productive resources and final products, servitisation, pay-per-use or subscription models, all moving us towards a collaborative or sharing economy.

In examining the possibility of design and implementation of circular business models in the field of textile and clothing industries, it is necessary to start with the basic principles of the circular economy and other factors which have a fundamental impact on the nature and intensity of implementation into the practice of business operators active in the sector (legislation, information, technology/innovation, design, financing, education). The current literature sporadically deals with the theme of circular business models in the field of textiles and clothing. In the current literature, this topic is rather indirect or partial; its significant part is devoted to the material, technical and technological aspects of the issue, as well as the economic aspect of the textile industry's performance (Forman \& Carvalho, 2019; Shevchenko, Razvadovskaya, \& Marchenko, 2019). 
The useful starting point for examining the application of circular business models in the textile and clothing industry may be the knowledge in research of the circular business models in manufacturing industries and services (Upadhyay, 2019).

Publications also deal with the social responsibility of textile manufacturers and clothing makers in the context of circular economy (Daddi, Ceglia, Bianchi, \& de Barcellos, 2019; Kjaer, Pigosso, Niero, Bech, \& McAloone, 2019; Norris, 2019).

The potential environmental benefits of various systems of textile reuse and recycling have been assessed in the literature, using methods, such as life cycle assessment (LCA) (Sandin \& Peters, 2018). Paras et al. (Paras, Pal, \& Ekwall, 2017) reported a systematic overview of the literature, which is devoted to the examination of the value chain based on reuse in the textile and clothing industry.

The literature also presents studies dealing with recycling in the textile sector (Gigli, Landi, \& Germani, 2019; Leal Filho et al., 2019).

The creation of an interdisciplinary approach in the supply chain in the field of textile and clothing industry through circulation and digitization is dealt with by Pal and Sandberg. They emphasize that the creation of interdisciplinary approaches and values in the supply chain of circular clothing is the result of the cooperation of all its members. They also point out that the basis for such a cooperation is the joint development of knowledge and business, comprehensive integration and information transfer. The development of new supply chain structures and models is considered a key ability of textile and clothing companies in a changing business environment (Pal \& Sandberg, 2017).

In the literature, in addition to the concept of circular business models, the concept of sustainable business strategy in the textile and clothing industry (Muthu, 2018) is also emerging. Other authors, in connection with the introduction of circular models in the textile and clothing industries, provide a holistic approach and emphasize the design. They explore the benefits of sustainable design in the deployment of the circular economy, define business models and production systems that will support the circular economy and propose a vision for circular business models in the textile and clothing industry based on the sustainable design (Smith, Baille, \& McHattie, 2017). The cooperation of textiles and clothing manufacturers with designers is accentuated (Norris, 2019).

The development and implementation of the principles of the circular economy in the textile and clothing industry based on reverse logistics is also the subject of literature (Wang, Ding, \& Wu, 2010).

The conceptual view of the systems and models of the circular economy is presented by Kumar and Suganya. They focus on the possibility of a change in the business model and the adoption of new initiatives in the field of textiles and clothing related to consumption and sustainability, the potential opportunities involved, the competitive advantage and the social, economic and environmental dimension of circular economy in these areas (Kumar \& Suganya, 2019).

The valuable knowledge brings the research that focuses on obstacles to the transition of business operators in the textile and clothing industry (Staicu \& Pop, 2018). 
The limits of the present linear economy model (take-make-waste) are particularly conspicuous in examining the textile and clothing industry. The change from the linear to the circular model requires knowledge, awareness, and engagement of all market participants: manufacturers, technology designers, legislators, and consumers. The speed and success of these changes will be very dependent on consumers ' choices, on the amount and quality of products they buy, on their openness to new business models, and on the manner of dealing with used products (Koszewska, 2018).

\section{Data and methods}

\subsection{Background to the study}

In the article, the focus was on the essence of the circular economy as a starting point for the development of circular business models and their integration into the practice of entrepreneurs - producers in the textile and clothing industry. Subsequently, we dealt with the theoretical aspects of our research, which are circular business models and their application in the field of textile and clothing industries. We drew literary resources mainly from the relevant databases of Web of Science and Scopus.

Based on the current theme of the circular economy and the forthcoming changes concerning its implementation in the textile and clothing sector, we have first implemented broader, quantitative research in order to ascertain the readiness of the entrepreneurs to move from a linear to the circular economic model. In our article, we have focused on the potential of the producers surveyed with a view to introducing new circular business models into their business activities. We later extended the research into a qualitative research approach aimed at examining the core of the problem - circular business models in relation to the attitudes, motivation and expectations of the companies surveyed towards the anticipated changes.

The textile and clothing industry in Slovakia is a sector that is currently facing the obligations arising from the legislation concerning waste management. In order to avoid waste treatment that draws resources from lower levels of the waste hierarchy, to increase the rate of preparation for reuse and recycling rate, to enable high-quality recycling and to promote the use of quality secondary raw materials, member states of the European Union should ensure better compliance with the obligation to carry out sorted collection, including the obligation to establish a selective collection of textile waste. With the recently adopted EU waste package, member states must assume important new obligations. These include ambitious recycling and landfill-reduction targets for 2030/2035, mandatory waste prevention measures and reinforced rules on separate collection of waste. In regard to selective collections schemes, member states shall particularly ensure that by 01 January 2025 separate collection schemes are set up for textiles waste produced by households. The new obligations have to be transposed in the national matter within a 2-year period. So far, in the EU there is rather limited experience with a separate collection of textiles, as only $15-20 \%$ are separately collected, while the vast majority ends landfilled or incinerated. Furthermore, there are large differences among the different member states in terms of how they manage this waste stream and the performances they have. Apart from France where a nationwide mandatory EPR scheme for textile products has been in place since 2008 - initiatives are scattered and mostly driven by government or individual brand owners. 
Data on the clothing and textile industry were obtained from data published by the Statistical Office of the Slovak Republic. When defining the clothing and textile industries, we have focused on the statistical classification of the economic activities of the SK NACE Rev. 2, issued by the Decree of the Statistical Office of the Slovak Republic of 18 June 2007 No 306/2007 Coll. In view of the divergence in the business activities of the investigated entities (producers), we have defined them to achieve better transparency in the researched sector (Tab. 1).

Table 1 | Overview of activities in the textile and clothing industry in the Slovak Republic

\begin{tabular}{|c|c|c|}
\hline Classification & Textile industry & Apparel industry \\
\hline Division & Textiles production & Manufacture of garments \\
\hline Group & $\begin{array}{c}\text { Preparation and spinning of } \\
\text { textile fibres }\end{array}$ & $\begin{array}{l}\text { Manufacture of garments other } \\
\text { than fur garments }\end{array}$ \\
\hline Group & Textile weaving & - \\
\hline Group & Textiles finishing & - \\
\hline Group & Manufacture of other textiles & - \\
\hline Class & $\begin{array}{c}\text { Manufacture of knitted and } \\
\text { crocheted textiles }\end{array}$ & Manufacture of leather Garments \\
\hline Class & $\begin{array}{l}\text { Manufacture of textile } \\
\text { products other than garments }\end{array}$ & Manufacture of working clothes \\
\hline Class & $\begin{array}{c}\text { Manufacture of carpets and } \\
\text { mats }\end{array}$ & $\begin{array}{c}\text { Manufacture of other high-quality } \\
\text { clothing }\end{array}$ \\
\hline Class & $\begin{array}{l}\text { Production of ropes, cords, } \\
\text { strings and nets }\end{array}$ & Manufacture of underwear \\
\hline Class & $\begin{array}{c}\text { Manufacture of non-woven } \\
\text { textiles and articles thereof, } \\
\text { excluding garments }\end{array}$ & $\begin{array}{c}\text { Manufacture of other garments } \\
\text { and accessories }\end{array}$ \\
\hline Class & $\begin{array}{c}\text { Manufacture of other technical } \\
\text { and working textiles }\end{array}$ & - \\
\hline Class & Manufacture of other textiles & - \\
\hline Group & - & Manufacture of fur products \\
\hline Group & - & $\begin{array}{l}\text { Manufacture of knitted and } \\
\text { crocheted garments }\end{array}$ \\
\hline Class & - & $\begin{array}{l}\text { Manufacture of knitted and } \\
\text { crocheted garments }\end{array}$ \\
\hline Class & - & $\begin{array}{l}\text { Manufacture of knitted and } \\
\text { crocheted garments }\end{array}$ \\
\hline
\end{tabular}

Source: self-processed according to the Statistical Office of the Slovak Republic (2007)

The implementation of innovative business models in the field of textile and clothing industry is thus a challenge that the sector is facing. Slovakia, as an EU member state, is facing the same challenge. Bodies operating in the textile and clothing industries must be gradually prepared for changes that bring the legislation and get ready for the trends that determine the changes mentioned.

\subsection{Quantitative and qualitative survey}

As mentioned above, in our paper, we list the partial results (1) of quantitative research that show the potential of the companies surveyed, coupled with the implementation of new circular business models into their activities. These results have formed a basis for (2) 
qualitative research focusing on perceptions, attitudes, expectations and motivation regarding the new economic and business model examined by the producers, with an emphasis on the advantages, disadvantages and limits of this procedure.

We carried out a quantitative survey on a sample of 122 Slovak clothing and textile companies (producers). To evaluate the results of the survey, we have used the mathematical-statistical technique - a cluster analysis with the goal to divide the objects of exploration into similar groups, which have been included in clusters.

The mathematical formulation of the cluster analysis has the following form: the grouping of objects $X_{i}(i=1,2, \ldots, N)$ is included in clusters $C_{1}, C_{2}, \ldots, C_{q}(2 \leq q \leq n)$ so that the objects are as similar as possible within the cluster and the objects included in various clusters are similar to the least. For a better interpretation, we applied the hierarchic arrangement of clusters - dendrogram (Stankovičová \& Vojtková, 2007).

In our paper, we used the agglomerative hierarchical process of clustering, since we did not know the initial number of clusters. Based on the results obtained by the hierarchic methods, we have decided on the Ward method, which is prevalently known as the most accurate one. The Ward method is the only method by which the criterion is the minimal determinant of the matrix of intracluster variability. Mathematically, the variability can be expressed as:

$$
\begin{gathered}
W=\sum_{j=1}^{k} W_{j}=\sum_{s=1}^{m} \sum_{i=1}^{k}\left(x_{s i}-\bar{x}_{s}\right)^{2} \\
B=\sum_{s=1}^{m} \sum_{j=1}^{k} k\left(\bar{x}_{s j}-\bar{x}_{s}\right)^{2}
\end{gathered}
$$

W - Variability of the intracluster component for $m$ clusters

$\mathrm{B}-$ Intercluster variability.

The Ward method joins clusters so that the increase in W was small and the increase in B bigger (Terek et al., 2010).

After the evaluation of results of the quantitative survey, we carried out a qualitative survey in the form of an interview - a semi-structured Interview method In-Depth Interviews (IDI) on a sample of 33 respondents. These were managers of companies that participated in the first survey. Their selection focused on the representatives of the formed clusters (cluster 1 $=10$ respondents, cluster $2=10$ respondents, cluster $=10$ respondents and cluster $3=3$ respondents).

To evaluate respondents ' replies, the Grounded Theory Method (GTM) has been used, which consists of an analysis of theoretical knowledge obtained on the basis of semistructured interviews.

For objectivity, the following triangulation has been applied: (1) Two research methods, (2) the interview was carried out by two researchers, (3) the findings were evaluated from two 
perspectives: the current and the potential situation. The respondents were guaranteed anonymity, so the results are processed for all participants at the same time.

In particular, the following areas were the subject of the interview: The current awareness of respondents, attitudes and motivation to the forthcoming measures, advantages, disadvantages and obstacles with the transition to the circular economy, the current and potential readiness of the entities surveyed for the implementation of circular business models into their activities.

Based on systematic data collection from the area, we have verified processes that have been regularly repeated or have common characteristics. By using qualitative research, we have gained a deeper understanding of those factors of the transition of the surveyed entities to circular business models that are paramount for their successful implementation.

\section{Results and discussion}

\subsection{Evaluation of the quantitative survey}

The results of our survey are based on the responses of several companies concerning anticipations from the implementation of the circular economy. The questions were formulated in a way to obtain the "yes" or "no" answers, which were then encoded in the analysis using the binary variable "yes $=1$ " and "no $=0$ ". As mentioned before, after considering the suitability of several hierarchic methods, we have opted for the Ward method. Since this is a hierarchic method, the result is a dendrogram (cluster tree).

The model enters the dependent and independent variables: dependent variable companies and independent variable - areas in which companies expect/do not expect improvement:

- growth of revenues

- expansion of output

- $\quad$ better competitiveness

\section{Expect improvement -1}

Do not expect improvement - 0

To properly divide objects into clusters, we need to know the ideal number of clusters to remove separate observations or an unnecessarily large number of clusters. To assess the number of clusters, we use the Scatter Plot.

On the scatter plot, we see that the ideal number is 4 clusters. Scatter Plot also shows the accuracy of the model, since the coefficient of determination (RSQ) should approach the 1 and the semi-partial coefficient of determination (SPRSQ) should be approximated to 0 . In our case $\mathrm{RSQ}=0.944$ and $\mathrm{SPRSQ}=0.0541$ (Fig. 1). 


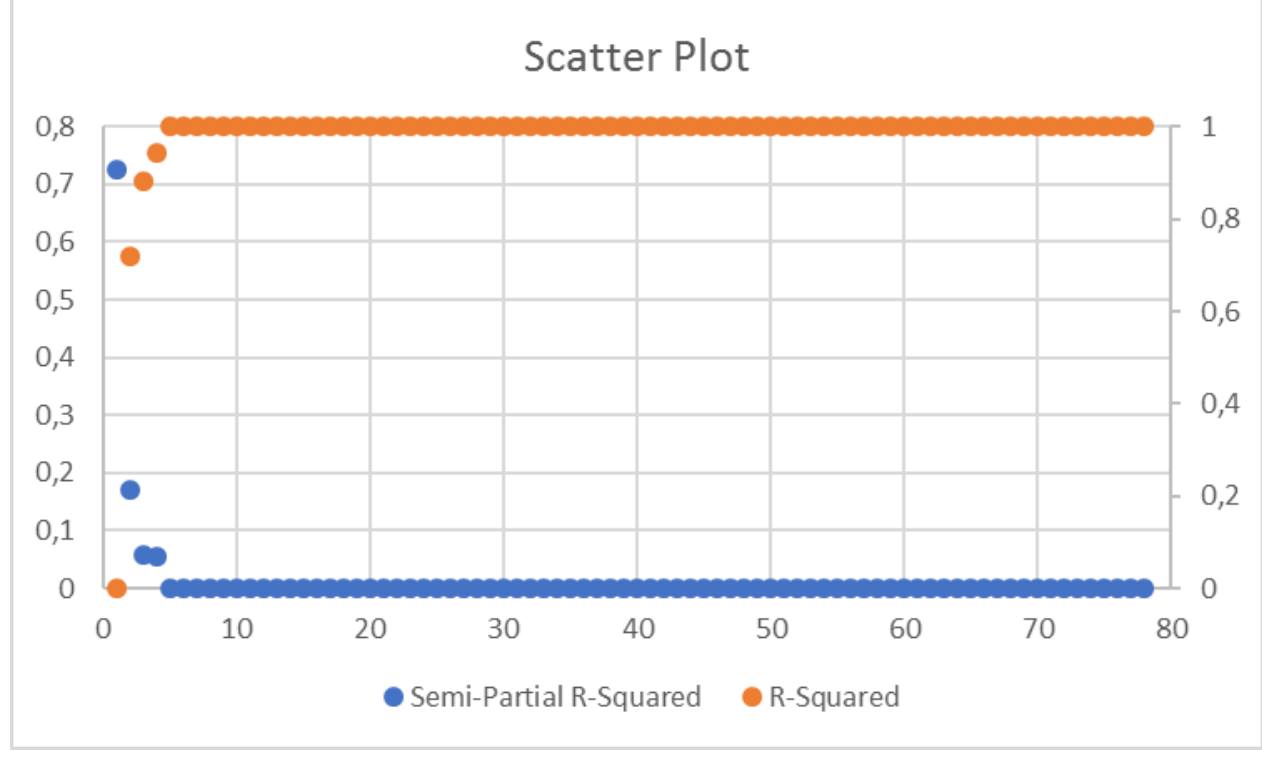

Source: authors based on their own data

Based on the determination of the optimal number of clusters, we created a dendrogram.

By using the Dendrogram, one can observe the structure and distribution of data into several clusters. The dendrogram shows joining companies at different levels, and so the most numerous groups can be inferred.

From Dendrogram, we observe that the theoretical condition is met, and we do not see any isolated observations (objects) (Fig. 2).

For a better interpretation of the results and characteristics of the individual clusters, we will show the summary statistics procedure.

Summary Statistics shows the absolute frequency of the clusters CLUSTER $1=48$, CLUSTER 2 = 17, CLUSTER 3 = 10, CLUSTER 4 = 3 (Tab. 2).

CLUSTER 1 - Companies represented in the first cluster expect improvements in all areas. These companies either have an established circular economy or have a high probability of implementing it.

CLUSTER 2 - Companies represented in the second cluster expect particularly sales growth and a small degree of production expansion. This cluster is largely represented by small enterprises, which are just about the implementation of the circular economy they consider a new business opportunity to achieve higher revenues.

CLUSTER 3 - The third cluster is made up of companies that do not even consider implementing a circular economy.

CLUSTER 4 - The fourth cluster is created by companies that expect to increase sales, but also better competitiveness. In terms of cluster occupancy, they are medium-sized enterprises that are currently achieving maximum production capacity. 
Figure 2 | Cluster Analysis Tree Chart

Cluster Analysis Tree Chart

The TREE Procedure

Cluster tree data for WORK.EXCEL_CE

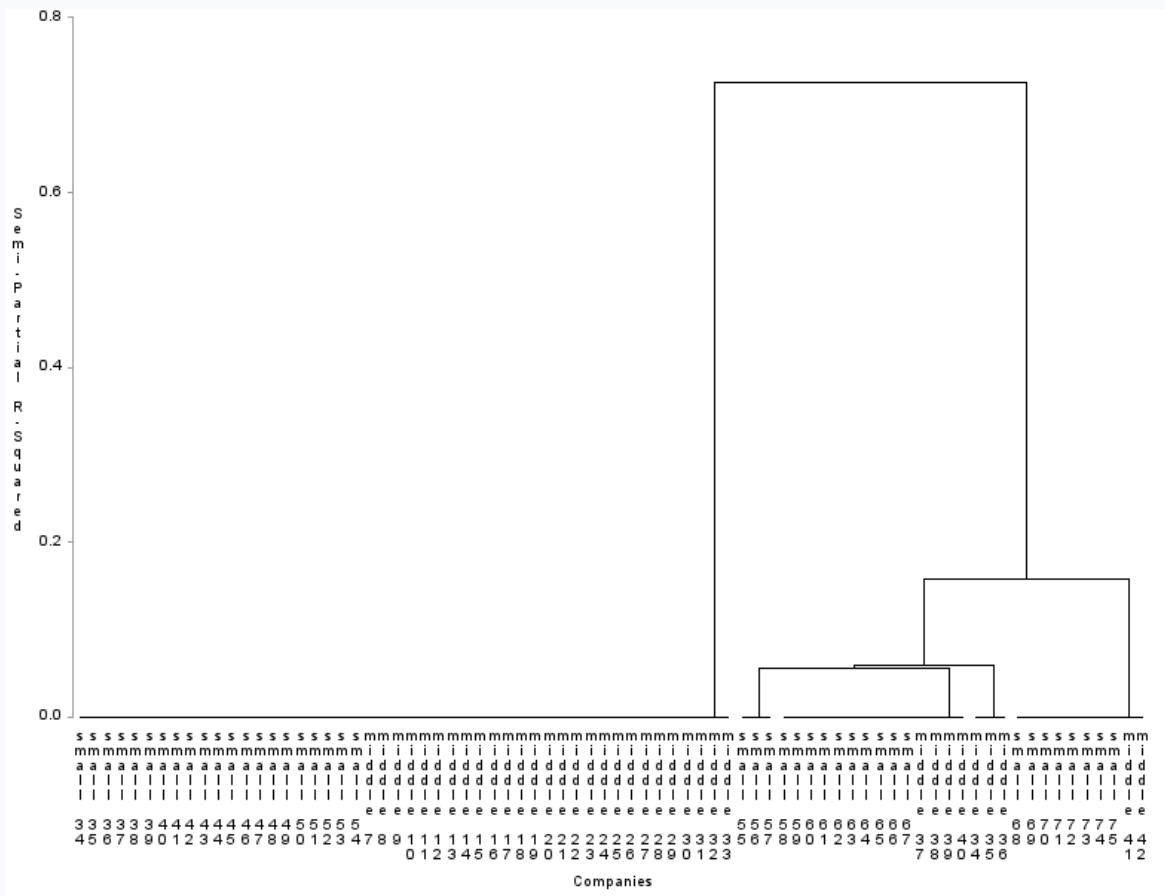

Source: authors based on their own data

Table 2 | Summary Statistics

\begin{tabular}{|c|c|c|c|c|c|c|c|}
\hline CLUSTER & $\mathbf{N}$ & Variable & Mean & Std Dev & Minimum & Maximum & $\mathbf{N}$ \\
\hline \multirow{3}{*}{1} & \multirow{3}{*}{48} & Growth of revenues & 1.0000000 & 0 & 1.0000000 & 1.0000000 & 48 \\
\hline & & \multirow{2}{*}{$\begin{array}{c}\text { Expansion of output } \\
\text { Better } \\
\text { competitiveness }\end{array}$} & 1.0000000 & 0 & 1.0000000 & 1.0000000 & 48 \\
\hline & & & 1.0000000 & 0 & 1.0000000 & 1.0000000 & 48 \\
\hline \multirow{3}{*}{2} & \multirow{3}{*}{17} & Growth of revenues & 1.0000000 & 0 & 1.0000000 & 1.0000000 & 17 \\
\hline & & Expansion of output & 0.1764706 & 0.3929526 & 0 & 1.0000000 & 17 \\
\hline & & $\begin{array}{c}\text { Better } \\
\text { competitiveness }\end{array}$ & 0 & 0 & 0 & 0 & 17 \\
\hline \multirow{3}{*}{3} & \multirow{3}{*}{10} & Growth of revenues & 0 & 0 & 0 & 0 & 10 \\
\hline & & \multirow{2}{*}{$\begin{array}{c}\text { Expansion of output } \\
\text { Better } \\
\text { competitiveness }\end{array}$} & 0 & 0 & 0 & 0 & 10 \\
\hline & & & 0 & 0 & 0 & 0 & 10 \\
\hline \multirow{3}{*}{4} & \multirow{3}{*}{3} & Growth of revenues & 1.0000000 & 0 & 1.0000000 & 1.0000000 & 3 \\
\hline & & \multirow{2}{*}{$\begin{array}{c}\text { Expansion of output } \\
\text { Better } \\
\text { competitiveness }\end{array}$} & 0 & 0 & 0 & 0 & 3 \\
\hline & & & 1.0000000 & 0 & 1.0000000 & 1.0000000 & 3 \\
\hline
\end{tabular}

Source: authors based on their own data 


\subsection{Summary of the results of the qualitative survey}

The best expertise and understanding of the principles of the circular economy, as well as the forthcoming related changes (legislation, technical, technological and logistic) in the field of textiles and clothing in Slovakia, has been noticed in medium-sized companies, which have also proved positive attitudes towards these facts. These companies already have some measures in place to implement the principles of the circular economy into their activities or to prepare them progressively (for example, the organization of producer responsibility/extended producer responsibility). The survey showed that such companies are set up very responsibly towards their forthcoming business, dominated by (1) economic motives against the environmental ones and (2) the legislative measures in preparation. These companies have declared that more than ever, attention will be paid to customers ' expectations. Many of the companies surveyed have begun to create partnerships with suppliers. The benefits are seen in a common share of some expenditures, in common marketing-oriented on the existing and particularly potential customers, and they see a prospect of an increase in sales.

Companies surveyed are mostly concerned about rising entry costs in insufficient market capacity (low demand, in particular by existing customers). Other phenomena that resonated with the managers surveyed were high technological and logistical difficulty, which they linked to the increase of financial demands in implementing circular business models.

The biggest obstacle to the smooth introduction of this model regarded by the respondents is the lack of awareness by the governance, even though they have brought a good awareness of the interviews. However, it has been proved that this scepticism stems mainly from experience regarding other changes and measures taken by the governance where all the information that the governance communicates to entrepreneurs is fast and incomplete. The measures linked to the information communicated are, according to the respondents, "sewn with a hot needle", which they also foresee in this case. They would appreciate, if the governance, in view of the reported term of the validity of the amended changes, has begun to prepare the necessary measures in this period, in order to obtain sufficient time to implement them (particularly finance and technology, followed by qualified employees). It is worth noting the concern of the companies surveyed, related to the need for an increase in production and, in particular, vertical diversification because of the increased needs and expectations of customers on the one hand and the lack of market potential on the other.

These companies belong to cluster 1, 2 and 4 . These companies have a high potential for a successful transition to new business models, subject to the elimination or reduction of the risk of administrative barriers, particularly in the legislative area and in the field of disseminating information. Furthermore, they pointed to the necessity of continuing research and development in the field of new fibres and textiles with the corresponding material characteristics, which will make easier to assess them (currently possible by the threading technique) and a new ecological design.

Companies belonging to cluster 3 proved the average potential for successful implementation of circular business models into their activities. These companies declared no interest in implementing new circular models into their business activities. It should be stressed that we have seen the highest dislocations in all the areas examined, which are 
likely to be based on their unwillingness to implement new business models in their practice and the absence of any expectations. The greatest shortcomings in their perception are mainly linked to lack of awareness - they do not possess any information or their awareness is incomplete and/or inaccurate. This deficiency concerns mainly the understanding of the principles of the circular economy. If they know something about it, they only connect it with environmental aspects or recycling. The absence of knowledge of the economic and social benefits of the new economic and business model has also been confirmed. Therefore, it is our view that the main core of the non-interest of the companies in question is related to this issue.

It is worth noting that, during the conduct of the interview, almost half of the respondents changed their attitudes towards the transition to circular business models and knew their potential expectations from the potential transition to the new business model (growth of income, the establishment of a network of partners and the compliance of business activities with legislation). However, according to them, this was particularly the result of sufficient availability of relevant information, sufficient time to create and, in particular, implement these changes into practice and better access to state credits.

Part of the respondents constituting cluster 3 did not change their view by emphasizing the current problems in their business activities (in particular financial and personnel), which, according to their terms, hinder them and will hinder the implementation of new business models. For these respondents, we have seen the greatest shortage in understanding the principles of the circular economy and its benefits as well as in the nature and intensity of informing these entrepreneurs about the subject concerned.

\subsection{Design of the circular business model of entities operating in the textile and clothing industry}

The creation of a universal model of circular business in the field of textile and clothing industry is difficult in the current period, taking into account the following factors:

- Different nature of the business activities of these entities.

- Absence of relevant and particularly complex research in the field.

- The absence of tools and/or conditions for the creation and implementation of these models in practice.

The following facts are currently in favour of the creation of a universal circular model in the textile and clothing industry:

- $\quad$ The relative size of business entities (small and medium-sized enterprises).

- The same starting conditions.

- The nature and dynamics of the business environment (technical and technological development, increasing interest of customers in circular products, legislation, etc.).

In the current phase of the transitional period for the circular economy in Slovakia, the most appropriate model appears to be the circular business five-phase model from Joustra et al., which is listed in the previous section of the paper (Joustra et al., 2013). This model is 
considered appropriate because of its usefulness, especially for small and medium-sized enterprises, in the event of a transition to a circular economy that operates in the textile and clothing sector in Slovakia and for its simplicity and transparency.

The first phase of this model, which concerns the general awareness, is crucial. Research has confirmed the importance of information to understand the changes that industry/industry is facing as well as the impact of information on the readiness of business operators to move to a new economic and business model. Partners, together with new business services, which companies are likely to have to offer are another prerequisite for the implementation of this process. At the same time, entrepreneurs and managers in the sector concerned will enable them to identify business opportunities in the new business concept.

In our view, however, we consider it necessary to pay much more attention to the needs and expectations of customers than the proposed model mentioned. Customers will create new markets with new needs, preferences and expectations, and they can create new business opportunity/opportunities. Customers will also be affected by new value chains of companies operating in the textile and clothing industry and are going to build a significant source of competitive advantage. It is also important to pay reasonable attention to competition and its power to reduce the effects of new business opportunities.

The original circular business model from the authors of Joustra et al. can represent the core of the transition to new business models of actors in the textile and clothing industry, in its current modification by highlighting the customer aspect and competition. However, we want to emphasize that the nature of the activities and the intensity of business and the nature of customers in the textile and clothing industry will gradually require several types and levels of tailor-made circular business models and not just one universal model.

\section{Conclusion}

The circular economy is not only a production philosophy. It is also a new concept of business that requires attention devoted to several of its aspects: environmental, social and not least the economic benefits. In order to ensure the interests of all the stakeholders, the priority should be given to favouring certain advantages/benefits over others. On the macro level, this requires quality legislation proposals and tools necessary for its implementation. On the micro-level, it will be necessary to take into account these instruments, technological developments, financial and source difficulty and business perspectives, determined by management and organizational development. Within both levels (macro-level and microlevel), it will be necessary to provide sufficient information and implement innovative educational approaches aimed at achieving a change in the perception of waste materials, circular products and circular business models and their competitive advantage, by both producers and customers.

The right and sufficient information are considered a prime determinant in implementing circular business models into the practice of business operators because of their clear significant share of deepening knowledge of the circular economy and understanding its nature and benefits. Another prerequisite for a successful transition of business operators from linear to the circular business model should be creating sufficient space for its implementation, both by the availability of information and education, but also better access 
to funding, particularly of initial entry costs and a formation of a space for cooperation among all parties involved (producers, designers, retailers). Finally, yet importantly, new innovative technologies and new matrix properties for textiles will be needed, which requires more intensive and targeted research and cooperation on the part of material researchers.

\section{Acknowledgement}

The paper is part of the VEGA project $1 / 0380 / 17$, elaborated at the Faculty of Commerce of the University of Economics in Bratislava, Slovak Republic.

\section{References}

Andersen, M. S. (2006). An introductory note on the environmental economics of the Circular economy. Sustainable Science Journal, 2, 133-140. https://doi.org/10.1007/s11625-006-0013-6.

Bakker, C., Wang, F., Huisman, J. \& den Hollander, M. (2014). Products that go round: Exploring product Life extension through design. Journal of Cleaner Production, 69, 10-16. https://doi.org/10.1016/j.jclepro.2014.01.028.

Bocken, N. M., Short, S. W., Rana, P., \& Evans, S. (2014). A literature and practice review to develop sustainable Business model archetypes. Journal of Cleaner Production, 65, 42-56. https://doi.org/10.1016/j.jclepro.2013.11.039.

Boons, F. \& Lüdeke - Freund, F. 2013 Business models for sustainable innovation: state -Of - the-art and steps towards a research agenda. Journal of Cleaner Production, 45, 2012-9. https://doi.org/19/j.jclepro.10.1016.

Boulding, K. E. (1966). The economics of the coming spaceship earth. Environmental Quality in a Growing Economy: Essays from the Sixth RFF Forum.

Daddi, T., Ceglia, D., Bianchi, G., \& de Barcellos, M. D. (2019). Paradoxycal tensions and corporate sustainability: And focus on Circular economy business cases. Corporate Social Responsibility and Environmental Management, 26(4), 770 - 780. https://doi.org/10.1002/csr.1719.

De Jong, E., Engelaer, F. \& Mendoza, M. (2015). Realizing Opportunities of a Circular Business Model. Retrieved May 10, 2019, from http://circulatenews.org/2015/04/de-lage-landen-realising-theopportunities-of-a-circular-business-model.

Ellen MacArthur Foundation (2015). Delivering the Circular Economy a Toolkit for Policymakers. Cowes, UK: Ellen MacArthur Foundation.

Forman, G. S. \& Carvalho, C. (2017). Design of sustainable textiles through biological systems and materials - innovative narratives within the circular economy. In Montagna, G. \& Carvalho, C. (Eds.). Textiles, identity and innovation: Design the future, pp. 373-378. Proceedings of the 1st Textile Design International Conference on Textiles, Identity and Innovation. Lisboa: Lisboa School of Architecture.

Gigli, S., Landi, D., \& Germani, M. (2019). Cost-benefit analysis of a circular economy project: a study on Recycling system for end - of - life tyres. Journal of Cleaner Production, 229, 680-694. https://doi.org/10.1016/j.jclepro.2019.03.223.

Joustra, D. J., de Jong, E., \& Engelaer, F. (2013). Guided Choices: Towards a Circular Business Model. Lille: North-West Europe Interreg IVB. 
Kjaer, L. L., Pigosso, D. C., Niero, M., Bech, N. M., \& McAloone, T. C. (2019). Product/ServicesSystems for a Circular Economy: The Route Decoupling Economic Growth from Resources Consumption. Journal of Industrial Ecology, 23(1), 22-35. https://doi.org/10.1111/jiec.12747.

Koszewska, M. (2018). Circular Economy - Challenges for the Textile and Clothing Industry. AUTEX Research Journal, 18(4), 337-347. http://doi.org./10.1515/aut-2018-0023.

Koszewska, M. (2018). Circular economy in textiles and fashion-the role of a consumer. Circular economy. In S. S. Muthu (Ed.) Textile and Apparel: Processing, Manufacturing and Design (pp. 183-206). Cambridge: Wooodhead Publishing. https://doi.org/10.1016/B978-0-08-1026304.00009-1.

Kumar, S. \& Suganya, S. (2018). Systems and models for circular economy. In S. S. Muthu (Ed.) Textile and Apparel: Processing, Manufacturing and Design (pp. 169-181). Cambridge: Woodhead Publishing. https://doi.org/10.1016/B978-0-08-102630-4.00008-X.

Lacy, P., Rosenberg, D., Drewell, Q., \& Rutqvist, J. (2013). 5 Business Models that are Driving the Circular Economy. Retrieved March 5, 2019, from http://www.fastcoexist.com/1681904/5Business-Models-That-Are-Driving-the-Circular-Economy.

Lacy, P., Keeble, J., McNamara, R., Rutqvist, J., Haglund, T., Cui, M., ... \& Sharma, A. (2014). Circular Advantage: Innovative Business Models and Technologies to Create Value in a World without Limits to Growth. Chicago, IL, USA: Accenture.

Laubscher, M. \& Marinelli, T. (2014). Integration of Circular Economy in Business. In: Proceedings of the Conference: Going Green-CARE INNOVATION 2014, Vienna.

Leal Filho, W., Ellams, D., Han, S., Tyler, D., Boiten, V., Paco, A., ... \& Balogun, A. L. (2019). A review of the socio-economic advantages of textile recycling. Journal of Cleaner Production, 218, 10 20. https://doi.org/10.1016/j.jclepro.2019.01.210.

Lüdeke-Freund, F. (2010). Towards a Conceptual Framework of Business Models for Sustainability. In Knowledge Collaboration \& Learning for Sustainable Innovation. Proceedings of the ERSCPEMSU Conference, Delft, 2010.

Muthu, S. S. (Ed.). (2018). Circular Economy in Textile and Apparel: Processing Manufacturing and Design. Cambridge: Woodhead Publishing.

Norris, L. (2019). Urban prototypes: Growing local circular cloth economies. Business History, 61(1), 205 - 224. https://doi.org/10.1080/00076791.2017.1389902.

O'Rorke, M. (1988). Public information campaign on precycling. California: Prepared for City of Berkeley.

Osterwalder, A. \& Pigneur, Y. (2010). Business Model Generation: A Handbook forVisionaries, Game Changers, and Challengers. Hoboken, NJ, USA, 2010. John Wiley \& Sons.

Pal, S. \& Sandberg, E. (2017). Sustainable value creation through new industrial supplyChains in apparel and fashion. In the 17th World Textile Conference of Association - of Universities for Textile (AUTEXT)-Shaping of the Future of Textile Location. Greece, 2017. https://doi.org/10.1088/1757-899X/254/20/202007

Paras, M. K., Pal, R., \& Ekwall, D. (2017). Systematic literature review to develop a Conceptual framework for a reuse - based clothing value chain. The International Review of Retail, Distribution and Consumer Research, 28, 231258.https://doi.org/10.1080/09593969.2017.1380066 
Parlikad, A., McFarlane, D., Fleisch, E., \& Gross, S. (2003). The Role of Product Identityin End-of-Life Decision Making. Retrieved March 25, 2019, from https://www.alexandria.unisg.ch/21457/1/cam-autoid-wh017. pdf

Pearce, D. W. \& Turner, R. K. (1990). Economics of Natural Resources and the Environment. London: Harvester Wheatsheaf.

Piribauer, B. \& Bartl, A. (2019). Textile recycling process, state of the art and current Developments: A mini review. Waste Management \& Research, 37(2), 112-119. https://doi.org/10.1177/0734242X18819277.

Planing, P. 2015 Business Model Innovation in a Circular Economy Reasons for Non-Acceptance of Circular Business Models. Open Journal of Business Model Innovation, 1- 11.

Roome, N. \& Louche, C. 2015 Journeying Toward Business Models for Sustainability: A Conceptual Model Found Inside the Black Box of Organisational Transformation. Organisation \& Environment, 29(1), 11-35. https://doi.org/10.1177/1086026615595084.

Sandin, G. \& Peters, G.M. (2018). Environmental impact of textile reuse and recycling - A Review. Journal of Cleaner Production, 184, 353-365.https://doi.org/10.1016/j.jclepro.2018.02.266.

Scott, J. T. (2015) The Sustainable Business a Practitioner's Guide to Achieving Long -Term Profitability and Competitiveness. Sheffield, UK: Greenleaf Publishing.

Shevchenko, I. K., Razvadovskaya, Y. V., \& Marchenko, A. A. (2019). Russian Textile Industry: Past and Present. Terra Economicus, 17(1), 131-149. https://doi.org/10.23683/2073-6606-2019-171-131-149.

Smith, P., Baille, J., \& McHattie, L. S. (2017). Sustainable Design Futures: An open design vision for the circular Economy in fashion and textiles. The Design Journal, 20(1), S1938-S1947, https://doi.org/10.1080/14606925.2017.1352712.

Stahel, W. R. \& Reday-Mulvey, G. (1981). Jobs for Tomorrow: the Potential for Substituting Manpower for Energy. New York: Vantage Press.

Stahel, W. R. (2010). The Performance Economy. New York: Palgrave Macmillan.

Staicu, D. \& Pop, O. (2018). Mapping the interactions between the stakeholders of the Circular economy ecosystem applied to the textiles and apparel sector in Romania. Management \& Marketing. Challenges for the Knowledge Society, 13(4), 1190-1209. https://doi.org/10.2478/mmcks-2018-0031

Stankovičová, I. \& Votková, M. (2007). Viacrozmerné štatistické metódy s aplikáciami. Bratislava: lura Edition.

Stubbs, W. \& Cocklin, C. (2008). Conceptualizing a "Sustainability Business Model". Organisation \& Environment, 21(2), 103-127. https://doi.org/10.1177/1086026608318042.

Terek, M. et al. (2010). Híbková analýza údajov. Bratislava: lura Edition.

Tukker, A., \& Tischner, U. (2006). Product-services as a research field: past, present and future. Reflections from a decade of research. Journal of cleaner production, 14(17), 1552-1556. https://doi.org/1552-1556/j.jclepro.10.1016.

Upadhyay, A. et al. (2019). Investigating "circular business models" in the manufacturing and services models. Journal of Manufacturing Technology Management, 30(3), 590. https://doi.org/606. 10.1108/JMTM-02-2018-0063.

Van Renswoude, K., ten Wolde, A., \& Joustra, J. D. (2015). Circular Business Models. Part 1: An introduction to IMSA's Circular Business Model Scan. Retrieved January 25, 2019, from: 
https://groenomstilling.erhvervsstyrelsen.dk/sites/default/files/media/imsa_circular_business_m odels_-_april_2015_-_part_1.pdf.

Decree of the Statistical Office of the Slovak Republic No. 306/2007 Coll. as of 18 June 2007

Walter, L. (2016). Towards a 4th Industrial Revolution of Textiles and Clothing. A Strategic Innovation and Research Agenda for the European Textile and Clothing Industry. Brussel: Textile ETP.

Wang, L., Ding, X. \& Wu, X. (2010). Investigation on Reverse Logistics of Recycling Waste Textiles. In 3rd International Symposium of Textile Bioengineering and Informatics Location: Coll Textiles. Shanghai, 2010, 1546 - 1549.

Wirtz, B. W. (2011). Business Model Management: Design_Instruments_Success Factors. Dordrecht: Springer Science+Business Media B.V.

The research paper has been reviewed. | Received: September 19, 2019; Revised: October 24, 2019; Accepted: November 11, 2019; Prepublished online: February 5, 2020; Published: March 31, 2020 